
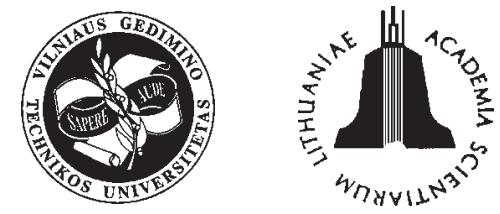

ISSN 1392-3730 print / ISSN 1822-3605 online

JOURNAL OF CIVIL ENGINEERING AND MANAGEMENT

http:/www.jcem.vgtu.lt

2006, Vol XII, No 1, 77-82

\title{
HEAT FLUX THROUGH THE TIMBER WALLS UNDER SUMMER CLIMATE CONDITIONS IN EASTERN EUROPE
}

\author{
Liutauras Kairys ${ }^{1}$, Vytautas Stankevičius ${ }^{2}$, Jūratė Karbauskaite் \\ ${ }^{1}$ Dept of Civil Engineering and Architecture, Kaunas University of Technology, Studentu g. 48, \\ LT-51367 Kaunas, Lithuania.E-mail: liutauras.kairys@one.lt \\ ${ }^{2}$ Institute of Architecture and Construction, Laboratory of Thermal Building Physics, Tunelio g. 60, \\ LT-44405 Kaunas, Lithuania.E-mail:25ilfiz@asi.lt; 3jukarb@asi.lt
}

Received 04 Nov 2005; accepted 05 Dec 2005

\begin{abstract}
The systems of air cooling and conditioning become more and more popular in Lithuania because of the reduced costs of equipment and installation. The popularity of the lightweight, heterogeneous and low thermal inertia envelops of buildings is increasing as well. Thus, there is a great demand for accurate methodology for calculation of non-steady state heat transfer that will take into account the solar radiation influences, convection and radiation inside partitions. Generally received building thermal behaviour calculation methods were designed for massive partitions, that is why they have to be re-verified according to the current situation. Thermal receptivity calculation methodology and a common engineering method are analysed in this paper according to experimental results. The research object is a well thermally isolated timber frame wall.
\end{abstract}

Keywords: thermo-physical parameters, solar radiation, lightweight timber frame partition, ventilated air gap.

\section{Introduction}

The temperature distribution inside multilayer lightweight partitions is effected not only by the temperature difference on the both surfaces of the partition, but by the directed solar radiation onto the external surface as well. The affect value depends on the thermal inertia of such a partition. It is necessary to compensate the additional cooling load caused by the solar radiation when designing air conditioning and cooling systems [1] for building envelope with a low thermal inertia.

There are fully or partly ventilated air gaps [2] installed in the well isolated $\left(>4,0 \mathrm{~m}^{2} \mathrm{~K} / \mathrm{W}\right)$ walls. The heat leakages through the connections of different materials occur during the service of the walls and depend on the construction quality. So there is an additional heat flux through the multilayer lightweight wall by convection and radiation [3] that have to be assumed into the whole heat exchange balance of the building envelope $[4,5]$.

Thus, there is a great demand for accurate methodology for calculation of non-steady state heat transfer that will take into account the solar radiation influences, convection and radiation inside partitions. The previous methodologies $[6,7]$ were designed for calculating thermo-physical processes inside massive partitions, that is why they have to be re-verified according to current situation. The lightweight walls contain the materials with very different physical parameters (thermal conductivity, density, thickness, specific heat capacity etc) [8]. So it is important to estimate precisely the designed values of different materials physical parameters and the effect of their interdependence to the heat storage and heat flux variation inside the wall $[9,10]$. The thermo-physical parameters (heat flux density, thermal inertia, time constant, thermal resistance, time lag, decrement factor etc) of the timber frame walls (Fig 1) are analysed in this paper. The calculated parameters are compared with the experimental data. The experiment was hold in the solar energy testing facility "Plataforma Solar de Almeria" in Spain [11] in Oct 2003-Jan 2004. The mentioned parameters were calculated by the methodology $[12,13]$ that estimates all the conditions discussed above. The methodology was designed in the seventies, but it is still used for calculating the heat transfer through the building envelope. Two types of the timber frame walls (Fig 1) with the common structure in the Eastern Europe region were chosen as the investigation object.

The aim of this paper is to compare the heat transfer through the discussed walls calculated by different methodologies with the experimental results and to determine the reasons of these disagreements.

Climatic and indoor air parameters were measured. The measurements were performed from 01 Nov 2003 to 25 Jan 2004 with registration every $10 \mathrm{~min}$. The hour's 

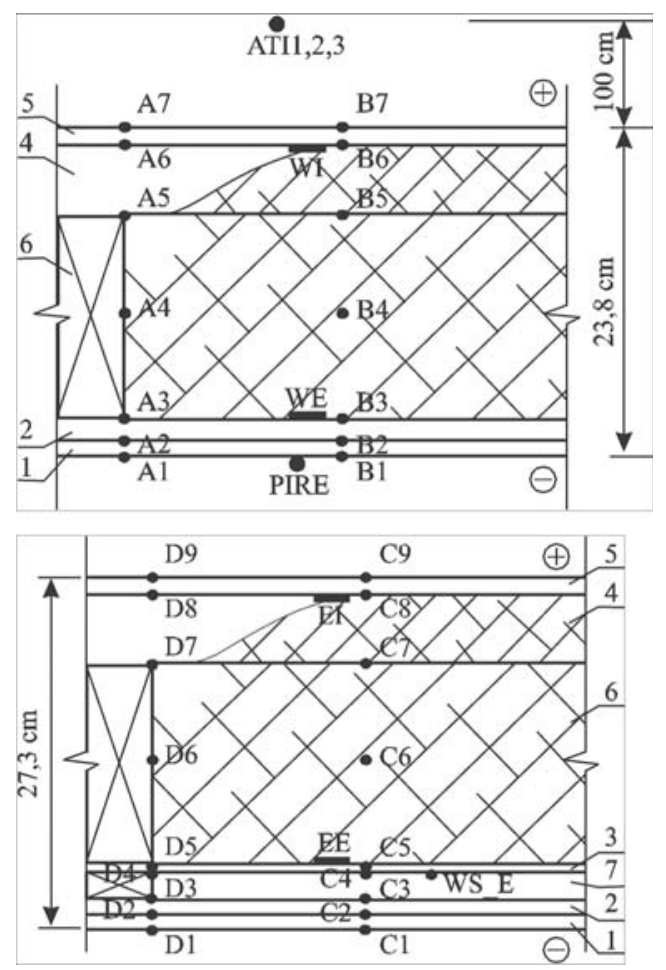

Fig 1. The cross-sections of walls and positions of measuring devices: 1 - plaster, $b=0,01 \mathrm{~m} ; 2$ - OSB (oriented strandboard), $b=0,015 \mathrm{~m} ; 3$ - plywood, $b=0,005 \mathrm{~m} ; 4-$ Cross beam $(50 * 50 \mathrm{~mm}$, step $600 \mathrm{~mm})$ with mineral wool inside, $b=0,05 \mathrm{~m} ; 5$ - gypsum plasterboard, $b=0,013 \mathrm{~m}$; 6 - timber frame $(150 * 50 \mathrm{~mm}$, step $600 \mathrm{~mm})$ with mineral wool inside, $b=0,15 \mathrm{~m} ; 7$ - vertically ventilated air gap, $b=0,03 \mathrm{~m}$

average values were calculated for each measured parameter and database of one-day mean hourly values with the precision of $95 \%$ was created. These values are presented in Table 1.

\section{Research results analysis}

Heat flux density (Thermopile TNO PU32), temperature (Thermopar TC B11T), wind speed (hot wire anemometer TSI 8455) and solar radiation density (pyranometer Kipp \& Zonen CM11) meters were installed in the walls for the experiment. The cross-sections of walls and positions of measure devices are shown in Fig 1.

Temperature distribution dynamics across wall section have been analysed first of all. A comparison of calculated and measured temperature wave oscillation amplitudes between walls layers clarified that there is no regular disagreement in the results. The higher temperature oscillation values on inner and outer surfaces and between gypsum plasterboard and thermal isolation were observed in experimental results. Higher temperature oscillation amplitude values on internal surfaces were obtained by calculations. The calculation results differences are shown in Table 2.
The calculation of temperature oscillation amplitudes is based on thermal receptivity [6] of wall materials and layers' surfaces. Indoor air temperature is constant, but there is no value set. Indoor air temperature during the natural research was kept constant and equal to $23{ }^{\circ} \mathrm{C}$. The average thermal receptivity of timber frame and thermal isolation layer is calculated according to methodology, but temperature next to the timber stud is $0,5^{\circ} \mathrm{C}$ higher than in the middle of mineral wool by experimental results. We can notify that calculated temperature oscillation values in internal layers of the walls are higher than the measured ones having situation opposite when analysing external layers. It can be concluded that thermal inertia of materials is not evaluated enough by the methodology, even if calculations are based on thermal capacity of materials.

Temperature oscillation amplitudes differences comparing by calculations and measurements are much larger in the wall with a ventilated air gap than in the one without air gap. The difference is so big (Table 2) that there are doubts about the methodology suitability for calculating of the temperature oscillation amplitudes in the walls with partly or fully ventilated air gaps. So, it is necessary to adjust the coefficients in equations that estimate air gaps influence on the temperature distribution dynamics.

Temperature wave attenuation is another basic parameter describing the wall thermal inertia. It is calculated in proportion to adjacent layers and surfaces thermal receptivity according to the methodology. Temperature oscillation amplitudes between layers were compared to the outer surface temperature oscillation amplitudes in order to get thermal wave attenuation measured during the experiment. The results and their percentage differences are in Table 3.

The results testify that calculated temperature wave attenuation in the wall without air gap does no differ a lot from experimental results $(6,1-22,9 \%)$ when in the wall with an air gap the difference is inadmissible $(25,0$ $67,4 \%$ ). We can notify also that after a thermal wave penetrates the thermal isolation in both types of the walls, the differences between the calculated and measured values decrease. The influence of thin layers with medium thermal receptivity to the temperature wave attenuation cannot be measured, calculated and estimated easily and properly.

Temperature wave attenuation values calculated by the methodology are lower than those obtained experimentally in every layer except for inner and 4-5 surfaces of the walls. One of the reasons can be wrongly accepted heat transfer coefficient on the internal surface of the wall and inaccurately calculated heat flow from the inner surface to the indoor air.

The measured heat flow densities through the lightweight timber walls were compared with the ones, calculated by thermal receptivity calculation methodology that takes into account the solar radiation and thermal inertia impacts. 
Table 1. Results of experiment at "Plataforma Solar de Almeria" in Spain

\begin{tabular}{|c|c|c|c|}
\hline Parameter & $\begin{array}{c}\begin{array}{c}\text { Average value } \\
\text { of the day }\end{array} \\
\end{array}$ & Parameter & $\begin{array}{c}\text { Average value } \\
\text { of the day } \\
\end{array}$ \\
\hline \multicolumn{4}{|c|}{ Temperatures, ${ }^{\circ} \mathrm{C}$} \\
\hline \multicolumn{2}{|c|}{\begin{tabular}{l|l} 
Wall without air gap. Measurement position - next to studs & \\
\end{tabular}} & \multicolumn{2}{|c|}{ Wall without air gap. Measurement position - between studs } \\
\hline \begin{tabular}{r|r|} 
A1 & \\
\end{tabular} & 12,1 & B1 & 11,8 \\
\hline $\mathrm{A} 2$ & 12,2 & $\mathrm{~B} 2$ & 11,5 \\
\hline $\mathrm{A} 3$ & 12,6 & B3 & 12,1 \\
\hline A4 & 15,1 & $\mathrm{~B} 4$ & 17,3 \\
\hline A5 & 17,9 & B5 & 19,1 \\
\hline A6 & 22,6 & B6 & 22,6 \\
\hline A7 & 22,8 & B7 & 22,8 \\
\hline \multicolumn{2}{|c|}{ Wall with air gap. Measurement position - next to studs } & \multicolumn{2}{|c|}{ Wall with air gap. Measurement position - between studs } \\
\hline \begin{tabular}{|l|l}
$\mathrm{D} 1$ & \\
\end{tabular} & 12,1 & $\mathrm{C} 1$ & 11,7 \\
\hline D2 & 11,9 & $\mathrm{C} 2$ & 11,6 \\
\hline D3 & 11,8 & $\mathrm{C} 3$ & 11,9 \\
\hline D4 & 12,2 & $\mathrm{C} 4$ & 12,5 \\
\hline D5 & 12,5 & $\mathrm{C} 5$ & 12,8 \\
\hline D6 & 15,6 & C6 & 15,3 \\
\hline D7 & 19,1 & $\mathrm{C} 7$ & 18,1 \\
\hline D8 & 22,7 & $\mathrm{C} 8$ & 22,3 \\
\hline D9 & 22,9 & C9 & 22,9 \\
\hline \multicolumn{4}{|c|}{ Heat flow, $\mathrm{W} / \mathrm{m}^{2}$} \\
\hline \multicolumn{2}{|l|}{ Wall without air gap } & \multicolumn{2}{|l|}{ Wall with air gap } \\
\hline WI Heat flux meter on inside surface & $-2,3$ & EI Heat flux meter on inside surface & $-2,1$ \\
\hline WE Heat flux meter on outside surface & 2,3 & EE Heat flux meter on outside surface & 2,5 \\
\hline \multicolumn{4}{|c|}{ Other parameters } \\
\hline ATI1 Inside air temperature $30 \mathrm{~cm}$ above the floor, ${ }^{\circ} \mathrm{C}$ & 22,8 & AVE1 Wind speed in $10 \mathrm{~m}$ height, $\mathrm{m} / \mathrm{s}$ & 2,0 \\
\hline ATI2 Inside air temperature $130 \mathrm{~cm}$ above the floor, ${ }^{\circ} \mathrm{C}$ & 22,9 & ADE1 Wind direction in $10 \mathrm{~m}$ height, ${ }^{\circ}$ & 193,8 \\
\hline ATI3 Inside air temperature $250 \mathrm{~cm}$ above the floor, ${ }^{\circ} \mathrm{C}$ & 23,0 & $\begin{array}{l}\text { ATE01 Outside air temperature in } 10 \mathrm{~m} \\
\text { height, }{ }^{\circ} \mathrm{C}\end{array}$ & 9,5 \\
\hline WS_E air velocity in ventilated air gap, $\mathrm{m} / \mathrm{s}$ & 0,069 & RHE1 Relative humidity in $2 \mathrm{~m}$ height, $\%$. & 70,9 \\
\hline \multirow[t]{2}{*}{ PIRE Solar radiation into the surface of the wall, $\mathrm{W} / \mathrm{m}^{2}$} & 160,8 & $\begin{array}{l}\text { GHE1 Solar radiation into horizontal surface, } \\
\mathrm{W} / \mathrm{m}^{2}\end{array}$ & 94,7 \\
\hline & & $\begin{array}{l}\text { DHE1 Diffused solar radiation into horizontal } \\
\text { surface, } \mathrm{W} / \mathrm{m}^{2}\end{array}$ & 46,4 \\
\hline
\end{tabular}

The positions of heat flux density meters inside the test-walls are shown in Fig 1. Heat flux densities were measured on inner and outer surfaces of the wall without air gap, inner and internal air gap surfaces of the wall with air gap. There are measured heat flow densities, solar radiation density and outdoor air temperature curves, calculated maximal heat flow densities from inner surfaces of the walls into the indoor air shown in Fig 2.

Table 2. Temperature oscillation amplitudes between wall layers

\begin{tabular}{|c|c|c|c|c|c|c|}
\hline \multirow{3}{*}{ Position } & \multicolumn{6}{|c|}{ Temperature oscillation amplitude, ${ }^{\circ} \mathrm{C}$} \\
\hline & \multicolumn{3}{|c|}{ Wall without air gap } & \multicolumn{3}{|c|}{ Wall with air gap } \\
\hline & $\begin{array}{l}\text { Experimental } \\
\text { results }\end{array}$ & $\begin{array}{l}\text { Calculation } \\
\text { results }\end{array}$ & $\begin{array}{c}\text { Calculation results difference } \\
\text { from experimental data, } \%\end{array}$ & $\begin{array}{l}\text { Experimental } \\
\text { results }\end{array}$ & $\begin{array}{l}\text { Calculation } \\
\text { results }\end{array}$ & $\begin{array}{l}\text { Calculation results difference } \\
\text { from experimental data, } \%\end{array}$ \\
\hline $\begin{array}{c}\text { Outer } \\
\text { surface }\end{array}$ & 22,5 & 18,4 & 18,2 & 20,9 & 15,6 & 25,3 \\
\hline $1-2$ & 20,3 & 20,7 & 1,9 & 21,1 & 17,6 & 16,6 \\
\hline $2-7$ & - & - & - & 17,1 & 19,1 & 11,7 \\
\hline $7-3$ & - & - & - & 13,2 & 14,2 & 7,5 \\
\hline $3-6(2-6)$ & 21,4 & 22,3 & 4,2 & 12,2 & 15,7 & 26,7 \\
\hline $6-4$ & 6,8 & 5,8 & 14,7 & 3,3 & 4,1 & 24,2 \\
\hline $4-5$ & 0,9 & 0,8 & 11,1 & 1,1 & 0,5 & 54,5 \\
\hline $\begin{array}{l}\text { Inner } \\
\text { surface }\end{array}$ & 0,8 & 0,6 & 25,0 & 0,9 & 0,4 & 55,5 \\
\hline
\end{tabular}

There was almost no heat inflow through the wall with air gap, because the inside air temperature of the test-room was constant and equal to $+23{ }^{\circ} \mathrm{C}$, and the outdoor air temperature oscillated from $+6,9$ to $+13,8^{\circ} \mathrm{C}$. There was obtained the relative error 0,17 for calculated heat flow density absolute values comparing with the measured ones for the wall with an air gap. The relative error for the wall without an air gap was just 0,057 . 
Table 3. Temperature wave attenuation during penetration through the walls

\begin{tabular}{|c|c|c|c|c|c|c|}
\hline \multirow{3}{*}{ Position } & \multicolumn{6}{|c|}{ Temperature wave attenuation, times } \\
\hline & \multicolumn{3}{|c|}{ Wall without air gap } & \multicolumn{3}{|c|}{ Wall with air gap } \\
\hline & $\begin{array}{l}\text { Experimental } \\
\text { results }\end{array}$ & $\begin{array}{l}\text { Calculation } \\
\text { results }\end{array}$ & $\begin{array}{l}\text { Calculation results difference } \\
\text { from experimental data, } \%\end{array}$ & $\begin{array}{l}\text { Experimental } \\
\text { results }\end{array}$ & $\begin{array}{l}\text { Calculation } \\
\text { results }\end{array}$ & $\begin{array}{l}\text { Calculation results difference } \\
\text { from experimental data, } \%\end{array}$ \\
\hline $\begin{array}{c}\text { Outer } \\
\text { surface }\end{array}$ & - & 1,1 & - & - & 1,11 & - \\
\hline $1-2$ & 1,0 & 0,9 & 10,0 & 1,0 & 1,0 & 0 \\
\hline $2-7$ & - & - & - & 1,2 & 0,9 & 25,0 \\
\hline $7-3$ & - & - & - & 1,6 & 1,2 & 25,0 \\
\hline $3-6(2-6)$ & 1,0 & 0,9 & 10,0 & 1,7 & 1,1 & 35,3 \\
\hline $6-4$ & 3,3 & 3,5 & 6,1 & 6,3 & 4,2 & 33,3 \\
\hline $4-5$ & 23,6 & 25,9 & 9,7 & 19,9 & 31,2 & 56,8 \\
\hline $\begin{array}{l}\text { Inner } \\
\text { surface }\end{array}$ & 27,4 & 33,7 & 22,9 & 24,2 & 40,5 & 67,4 \\
\hline
\end{tabular}

It is evident that maximal absolute heat flow density values on wall inner surface cannot be calculated precisely with the discussed methodology for the wall with an air gap. Meanwhile, the results can be obtained with acceptable precision for the wall without an air gap.

Heat flux density $q=2,5 \mathrm{~W} / \mathrm{m}^{2}$ through the wall without air gap and $q=2,19 \mathrm{~W} / \mathrm{m}^{2}$ through the wall with air gap were calculated by common engineering method $[14,15]$ :

$$
q=\frac{\left(\Theta_{i}-\left(\Theta_{e}+\frac{p \times I_{r, \text { max }}}{h_{s e}}\right)\right)}{R},
$$

where $\Theta_{i}$ - indoors air temperature $\left[{ }^{\circ} \mathrm{C}\right], \Theta_{e}$ - outdoors air temperature $\left[{ }^{\circ} \mathrm{C}\right], I_{r, \max }$ - maximal solar radiation density onto the wall $\left[\mathrm{W} / \mathrm{m}^{2}\right], h_{s e}-$ heat transfer coefficient on external surface of the wall $\left[\mathrm{W} /\left(\mathrm{m}^{2} \mathrm{~K}\right)\right], p-$ solar radiation absorbance of material [-].

The indoor $\left(+23,0^{\circ} \mathrm{C}\right)$ and outdoor air $\left(+9,8^{\circ} \mathrm{C}\right)$ temperatures from experimental measurements have been chosen. There was obtained the relative error 0,21 for calculated heat flow density absolute values comparing with the measured ones for the wall with an air gap. The relative error for the wall without air gap was 0,28 . These differences are much bigger than the ones, evaluated comparing experimental data and calculations by the analysed methodology $[6,7]$. The accurate heat flow

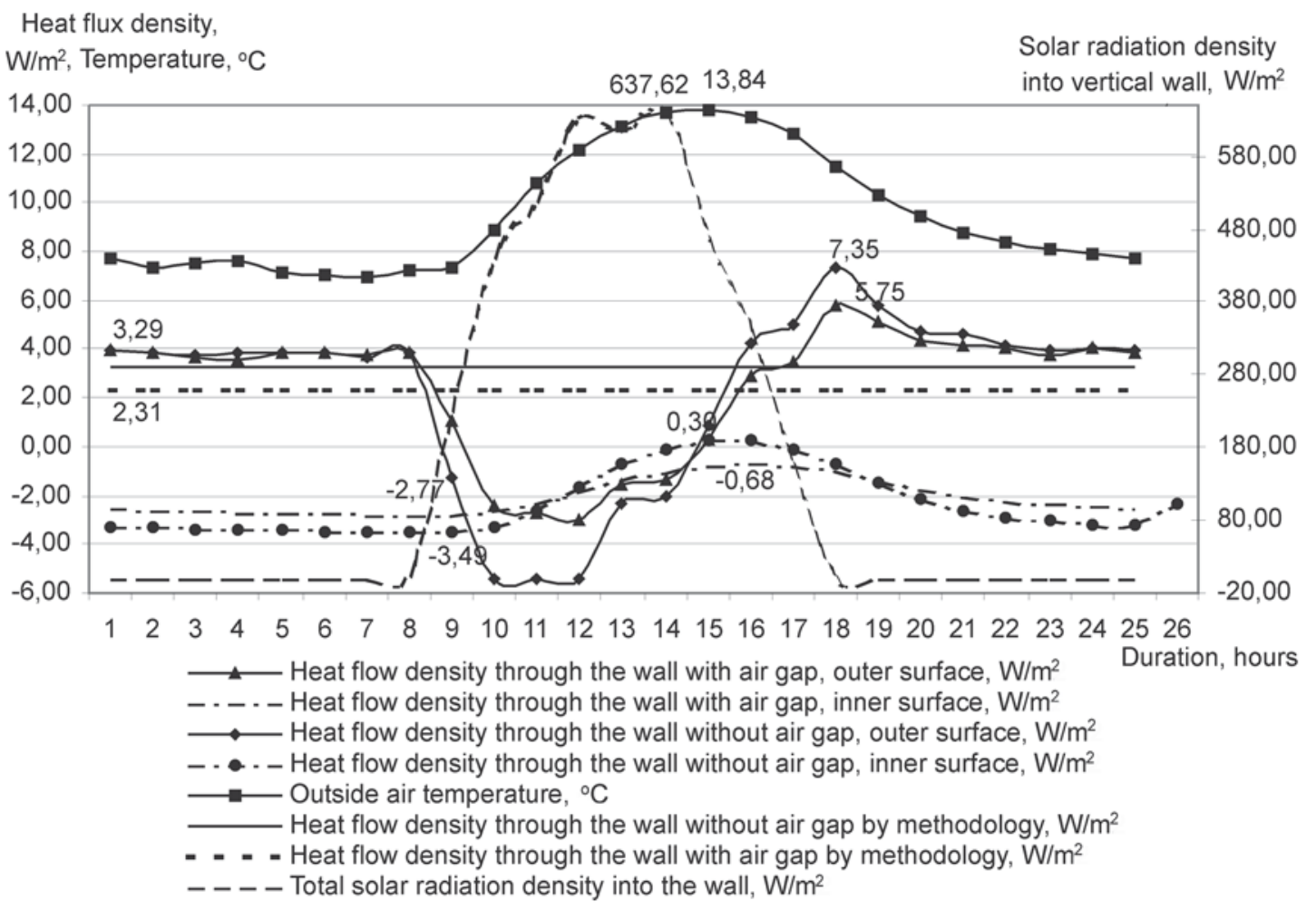

Fig 2. Calculated and measured experimentally heat flux density through the walls 
Table 4. Comparison example. The heat flow through $108 \mathrm{~m}^{2}$ walls

\begin{tabular}{c|c|c|c|c|c}
\hline \multicolumn{5}{c}{ Heat flow, W (relative error with experimental results, \%) } \\
\hline Experimental results & $\begin{array}{c}\text { Calculation by } \\
\text { methodology }\end{array}$ & $\begin{array}{c}\text { Calculation by } \\
\text { equation (1) }\end{array}$ & Experimental results & $\begin{array}{c}\text { Calculation by } \\
\text { methodology }\end{array}$ & $\begin{array}{c}\text { Calculation by } \\
\text { equation (1) }\end{array}$ \\
\hline $\begin{array}{c}376,9 \\
(0 \%)\end{array}$ & $\begin{array}{c}123,1 \\
(5,7 \%)\end{array}$ & $\begin{array}{c}299,2 \\
(0 \%)\end{array}$ & $\begin{array}{c}249,5 \\
(16,6 \%)\end{array}$ & $\begin{array}{c}108,0 \\
(64,0 \%)\end{array}$ \\
\hline
\end{tabular}

density through the discussed timber frame walls cannot be calculated precisely with a common engineering method.

The heat flow density oscillations were smaller in the wall with an air gap by measurements and calculation results as it was expected. It is clear from Fig 2 that the heat flow densities on outer surfaces of the walls have the shape of summed outside air temperature and solar radiation density curves and have 3-4 hours timelag.

An $100 \mathrm{~m}^{2}$ area building with $2,7 \mathrm{~m}$ height walls was analysed as an example. It has $108 \mathrm{~m}^{2}$ area of the walls. The heat flows through $108 \mathrm{~m}^{2}$ walls were calculated by three methods mentioned above. The results are presented in Table 4.

We could see in Table 4 that if we calculate the loads for cooling or conditioning systems by methodology, it will give just 5,7\% smaller heat inflow than in reality for the wall without air gap and 16,6\% smaller heat inflow through the wall with air gap. Calculating by equation (1), the system power will be by $67,0 \%$ too low for the building with the walls without an air gap and $64,0 \%$ too low for the building with the walls with a ventilated air gap. So, the simplified equation, which the designers are using (1), cannot assure precise heat flow values.

\section{Conclusions}

1. More than $50 \%$ of differences have been found while calculating the temperature wave oscillation amplitudes in the wall with the air gap by the methodology from experimental results. The coefficients in the methodology estimating the influence of the ventilated air gap on the results have to be revised.

2. While analysing the temperature wave attenuation, it was observed that thin layers with a moderate thermal receptivity are reducing the precision of the results when the thermal behaviour of timber frame walls is estimated.

3. After the analysis of heat flow it was clarified that it is possible to calculate the accurate absolute heat flow density values for the wall without an air gap only (the relative error with experimental results is 5,7\%). The analysed methodology has to be revised in order to get more precise heat inflow values through the timber frame walls with a ventilated air gap.
4. The accepted building thermal behaviour calculation methods cannot assure high-accuracy results for timber frame walls under the Eastern Europe summer time weather conditions.

\section{References}

1. Magzoub, E. E.; Osman, E. A. Computer simulation of solar cooled buildings in Khartoum. Renewable energy, 14 (1-4): May-Aug 1998, p. 373-379.

2. STR 2.01.03:2003. The declared and designed values of the building materials' thermal parameters (Statybiniu medžiagų ir gaminių šiluminių techninių dydžių deklaruojamosios ir projektinès vertès). Vilnius, 2003 (in Lithuanian).

3. Endriukaitytè, A.; Parasonis, J.; Samajauskas, R.; Bliūdžius, R. Estimation of effect of thermal convection on heat transfer through the building partitions. Journal of Civil Engineering and Management Vol 9, Suppl 1, 2003, p. 66-76.

4. Cabanillas, R. E.; Estrada, C. A.; Alvarez, G. Combined natural convection and radiation heat transfer in an open tilted cavity. Advanced computational methods in heat transfer, VII 4, 2002, p. 95-106.

5. Zuo, Z.; Hua, B.; Ye, G. D. The effect of PV walls on indoor air-conditioning load. In: Proceedings of the 3rd international symposium on heat transfer enhancement and energy conservation, Vols 1 and 2, 2004, p. 1164-1169.

6. Bogoslovski, V. Building thermal physics (Строительная теплофизика). Moscow, 1970 (in Russian).

7. Fokin, K. Building thermal technology (Строительная теплотехника). Moscow, 1973 (in Russian).

8. Bliūdžius, R.; Stankevičius, V. The manual of thermal physics (Statybinès šiluminès fizikos žinynas). Kaunas: Technologija, 2001 (in Lithuanian).

9. Koczyk, H. Selection of thermophysical properties of heat storage wall. Journal of Civil Engineering and Management, Vol VIII, No 4, 2002, p. 281-285.

10. Heim, D.; Klemm, P. Numerical solution of TIM-PCM solar thermal storage system with ESP-r. Research in building physics, 2003, p. 683-690.

11. www.psa.es

12. STR 2.09.04:2002. The power of building's heating system. Energy costs for heating. Lithuanian Department of the Environment (Pastato šildymo sistemos galia. Energijos sąnaudos šildymui). Vilnius, 2002 (in Lithuanian).

13. ТСН23-314-2000-Кал. О. The standard of the energy accumulated thermal protection of dwellings and public buildings (Нормативы (нормы) по энергосберегающей теплозащите жилых и общественных зданий). Kaliningrad, 2000 (in Russian). 
14. STR 2.05.01:1999. Thermal technology of building partitions. Environment Department of Lithuanian Republic (Pastatų atitvarų šiluminé technika). Vilnius, 1999 (in Lithuanian).
15. Parasonis, J.; Stankevičius, V. Thermal physics of buildings. Workbook (Pastatų šilumine fizika. Pratybos ir laboratoriniai darbai). Vilnius: Technika, 2000. 104 p. (in Lithuanian).

\section{ŠILUMOS MAINAI PER MEDŽIO KARKASO SIENĄ RYTŲ EUROPOS VASAROS KLIMATO SĄLYGOMIS}

\section{Kairys, V. Stankevičius, J. Karbauskaitė}

\section{Santrauka}

Oro vėsinimo ir kondicionavimo sistemos sparčiai populiarẻja Lietuvoje dèl vis mažèjančių įrenginių kainų ir eksploatacijos išlaidų. Naujai statomų pastatų konstrukcijoms vis dažniau naudojamos lengvos, daugiasluoksnès, tačiau mažai inertiškos atitvaros. Taigi atsiranda poreikis tiksliai apskaičiuoti nestacionariuosius šiluminius procesus, vykstančius minètose atitvarose, i̇vertinant saulès spinduliuotès įtaką, šilumos mainų dydį konvekcija ir spinduliuote. Dabartinès metodikos buvo kuriamos skaičiuoti vidutinių ir didelių atitvarų šiluminei būsenai, todèl jos turi būti patikrintos atsižvelgiant i dabartinius pokyčius.

Šiame straipsnyje analizuojama šiluminio imlumo skaičiavimo metodika ir paprastasis inžinerinis šilumos srauto tekejjimo per atitvaras skaičiavimo metodas palyginamas su eksperimento rezultatais. Tyrimo objektas - gerai apšiltinta $\left(\mathrm{R}>4,5 \mathrm{~m}^{2} \mathrm{~K} / \mathrm{W}\right)$ medinè karkasinè siena.

Raktažodžiai: šiluminès fizikos parametrai, saulès spinduliuoté, medinè karkasinè atitvara, vėdinamasis oro tarpas.

Liutauras KAIRYS. PhD student at the Dept of Civil Engineering and Management, Kaunas University of Technology, Kaunas, Lithuania. Author of several papers on thermal inertia problems in lightweight building envelope.

Vytautas STANKEVIČIUS. Prof Dr Habil. Head of the Building thermal laboratory at the Institute of Architecture and Construction of Kaunas University of Technology. Professor of the Dept of Civil Engineering and Architecture of Kaunas University of Technology. Member of Heating, Cooling and Air Conditioning Association.

Author of more than 200 articles and 4 inventions. Scientific interests: energy savings in buildings, the durability of outer surfaces of building envelope.

Jūratė KARBAUSKAITÉ. Doctor (techn sciences). Researcher at the Institute of Architecture and Construction of Kaunas University of Technology. The expert of Lithuanian Studies and Research Foundation. Research interests: energy savings in buildings, heat and mass transfer, heat losses through the building envelope. 